Diterbitkan oleh Pusat Studi Gender dan Anak LP2M IAIN Syekh Nurjati Cirebon, Indonesia

\title{
INTERVENSI PSIKOLOGIS PADA PEMEROLEHAN BAHASA ANAK
}

Halim Purnomo*

Universitas Muhammadiyah Yogyakarta halimpurnomo@umy.ac.id

- Received: 20 Nov 2019 •Accepted: 4 Des 2019 •Published online: 11 Des 2019

Abstract: Secara psikologis pemerolehan bahasa anak sangat dipengaruhi oleh komunitas di mana dia sering berada. Gaya bahasa yang akan digunakan anak sebagai alat komunikasi hasil dari apa yang sering didengar dan disaksikan. Bahasa bagi anak merupakan ciri khas wujud perkembangan diri anak secara spontan. Untuk memperoleh suatu bahasa, anak mempelajarinya melalui berbagai proses. Oleh karena itu secara umum anak-anak dapat belajar bahasa melalui media bahasa baik secara langsung maupun tidak langsung. Media langsung yang maksud merupakan media yang diberikan oleh orangtua, guru maupun tutor. Sedangkan media tidak langsung merupakan media yang diperoleh oleh anak biasanya pada saat berinteraksi dengan teman sebaya, mendengar dan menyaksikan dari media televisi maupun media lainnya serta pemerolehan bahasa dari aspek pendengaran yang diterima tanpa disadari, anak akan menerima apa yang didengar.

Kata Kunci: Corak dan warna bahasa anak, media belajar bahasa anak

Abstract: Psychologically, the acquirement of children's language hardly influenced by the community where the children are. The language's styles which will be used as the communication tool is the results of the hearing process and what the children have been seen. The language for children is a character of skills that grow in themselves spontaneity, without real effort or formal instruction, then it usually uses without understanding the basic logic. For acquiring a language, children have to learn it through various processes. Therefore, generally, children's language can be acquired from various media, it can be direct or indirect media. The direct media means media which has been given by parents, teachers or facilitator directly. And on the other hand, indirect media is media that has been acquired by children in general. For example when the interaction was being held; hearing or seeing from television or the other indirect media. Then, acquiring the language from the hearing aspect that has been accepted without realizing it, and children will accept what they have heard.

Keywords: children's language style, children's language learning media.

\section{A. PENDAHULUAN}

Beberapa factor yang mempengaruhi tumbuh kembang bahasa anak antara lain factor internal maupun eksternal. Pertumbuhan dan Perkembangannya melibatkan perubahan yang terjadi pada anak yakni terjadi secara bersamaan yang

\footnotetext{
* Corresponding Halim Purnomo, Email: halimpurnomo@umy.ac.id
} 


\section{Halim Purnomo}

disertai dengan perubahan fungsi-fungsi lainnya. Begitu juga dengan pemerolehan bahasa atau kata-kata bisa terjadi semenjak kanak-kanak dan proses pemerolehannya secara alami. Pemerolehan bahasa bagi anak adalah kemampuan diri untuk menangkap, menghasilkan, dan mengimplementasikan kata untuk memahami komunikasi berkenaan dengan bahasa pertama atau sering kali disebut dengan bahsa ibu. Bahasa yang telah diperoleh sebernarnya bukanlah bahasa yang rumit, hanya saja tingkatan ini merupakan pijakan pertama untuk menuju perkembangan bahasa selanjutnya.

Bahasa daerah merupakan bahasa pertama anak, selanjutnya akan menyusul kemampuan bahasa-bahasa lainnya seperti bahasa Indonesia dan bahasa asing lainnya yang termasuk kategori bahasa kedua anak. Era globalisasi menuntut mereka menguasai bahasa lisan dan tulisan. Karena dengan bekal itu, mereka dapat mempermudah menjalin komunikasi dengan siapapun secara luas.

\section{B. HASIL DAN PEMBAHASAN}

\section{Sumber Pemerolehan Bahasa Anak}

1. Proses belajar bahasa

Secara umum bahasa berfungsi sebagai alat komunikasi. Bahasa merupakan alat komunikasi yang menghubungkan individu yang satu dengan lainnya. Atas dasar itulah menurut Sudaryanto (1990) b ahasa akan selalu berkembang dengan segala fungsinya. Meilan, A (2014) menjelaskan bahwa proses belajar bahasa anak sangat terkait dengan proses belajar bahasa berikutnya. Jadi, pemerolehan bahasa berkenaan dengan Bahasa yang pertama, sedangkan pembelajaran bahasa berkenaan dengan bahasa kedua. Dalam Kamus Besar Bahasa Indonesia (KKBI), frase pemerolehan bahasa terdiri dari kata pemerolehan dan bahasa yang berarti proses dan cara memperoleh. Makna kata memperoleh juda dalam KBBI memiliki makna mencapai sesuatu dengan upay dan usaha. Dengan demikian kata memperoleh merupakan suatu proses dan cara memperoleh sesuatu melalui usaha dan upaya. Frasa memperoleh bahasa memiliki arti cara, perbuatan atau proses memperoleh bahasa dengan upaya dan usaha.

Oleh karena itu, proses pemerolehan bahasa merupakan kemampuan proses menangkap, menggunakan dan menghasilkan kata untuk memahami dalam segala proses komunikasi. Kapasitas ini tidak berdiri sendiri sehingga perlu melibatkan kemampuan-kemampuan tertentu seperti kosakata yang luas, 
fonetik, dan sintaksis. Bahasa lisan atau bahasa manual seperti isyarat yang diperoleh bsa berupa vocal. Pemerolehan bahasa pertama yang mengkaji anak memperoleh bahasa ibu, pemerolehan bahasa kedua dan seterusnya serta bahasa tambahan merupakan proses upaya dan usaha anak pada pemerolehan bahasa. Contoh bahasa telegram yang menekankan pengunaan content word untuk menyampaikan makna dijelaskan oleh Djuwarijah (2018) biasanya dialami oleh anak-anak usia 3-4 tahun yang masih belajar di play group.

Fonem dan morfem diujaran secara tidak lengkap biasanya terjadi pada anak usia 11-12 tahun sekolah di kelas 5 SD menggunakan sintaksis berupa kalimat lengkap yang terdiri dari subjek, predikat, objek dan keterangan. Ragam kosakata, klausa dan kosakata pinjaman juga muncul. Selanjutnya menurut Yudibrata (1998) menjelasakan dalam Sukmawati (2015) linguistic merupakan alat untuk memahami bahasa. Teori-teori bahasa atau yang disebut dengan istilah linguistic merupakan ilmu yang mengkaji bahasa, namun tidak demikian halnya dengan anak sebagai pemeroleh bahasa. Ilmu lain yang berkaitan dengan pemerolehan bahasa tidak hanya bisa dipahami dengan linguistic, tetapi hanya dapat dipahami dengan ilmu lain yang sangat berkaitan, yaitu psikologi

Jadi, pemerolehan bahasa bagi anak merupakan sebuah upaya sekaligus proses anak yang mampu mendapatkan kemampuan untuk menggunakan, menangkap, dan menghasilkan kata untuk pemahaman komunikasi berkenaan dengan bahasa pertama. Kemampuan komunikatif yang bermakna hanya dimiliki manusia. Artinya, tidak ada makhluk lain yang memiliki kemampuan komunikatif. Kenyataan bahwa anak-anak mampu memperlihatkan keseragaman dalam perkembangan linguistiknya merupakan sebuah deskripsi pada usia anak-anak produktif. Mackey (dalam Iskandarwassid, 2009) menjelasakan tahapan-tahapan pemerolehan bahasa bagi anak antara lain :

a. Umur 3 bulan: Anak pada usia ini mulai mengenal suara manusia, ingatan yang sederhana, tapi belum tampak sehingga segala sesuatu masih terkait dengan apa yang dilihatnya.

b. Umur 6 bulan: Anak pada usia ini sudah mulai mampu membedakan antara nada yang "halus" dan "kasar" seperti mulai membuat vokal seperti

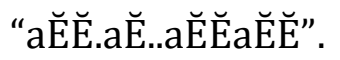

c. Umur 9 bulan: Anak pada usia ini mulai mampu berinteraksi dengan isyarat seperti mulai mengucapkan bermacam-macam suara. 
d. Umur 12 bulan: Anak pada usia ini mulai mampu membuat reaksi terhadap perintah seperti gemar mengeluarkan suara-suara dan bisa diamati, adanya beberapa kata tertentu yang diucapkannya untuk mendapatkan sesuatu.

e. Umur 18 bulan: Anak pada usia ini mulai mampu mengikuti petunjuk, biasanya kosakata sudah mencapai sekitar 20.

a. Umur 2-3 tahun: Anak pada usia ini sudah bisa memahami pertanyaan dan perintah sederhana. Kosa katanya sudah mencapai beberapa ratus dan sudah bisa mengutarakan isi hatinya dengan kalimat sederhana.

b. Umur 4-5 tahun: Pemahaman anak pada usia ini semakin mantap walaupun masih sering bingung dengan hal-hal yang menyangkut waktu. Anak mulai mampu belajar berhitung dan kalimat-kalimat yang agak rumit mulai digunakan.

c. Umur 6-8 tahun: Anak pada usia ini biasanya tidak ada kesukaran untuk memahami kalimat yang biasa dipakai orang dewasa sehari-hari. Anak-anak juga mulai mampu belajar membaca yang akhirnya menambah pembendaharaan kata.

Tarigan (1988) memberikan penjelasan yang berbeda terkait dengan keterangan perkembangan pemerolehan bahasa anak prasekolah dibagi menjadi 3 bagian, perkembangan prasekolah, ujar kombinatori, dan perkembangan masa sekolah.

a. Perkembangan prasekolah

1. Tahap pralinguistik

Pada tahap ini anak manusia secara pembawaan lahir "diperlengkapi" untuk interaksi social pada umumnya dan bahasa pada khususnya. Terbukti bayi lebih menyukai wajah manusia atau gambarnya, kepada objek nyata aau gambarnya. Pada usia 2 bulan anak memberi respon yang berbeda-beda terhadap orang dan objek.

2. Tahap Satu Kata

Pada tahap ini anak mulai mampu mengekspresikan begitu banyak katakata.

3. Ujaran Kombinatori Permulaan

Pada tahap ini ujaran kombinasi anak mulai berkembang dari suatu system yang kebanyakan merupakan gabungan dua atau tiga kata yang tidak berinfleksi, butir-butir yang berisi (nomina dan verba). 


\section{Halim Purnomo}

b. Perkembangan Ujaran Kombinatori

Perkembangan ini dibagi menjadi 3 yaitu peerkembangan negative yang terdiri dari penyangkalan; menggunakan kata 'tidak/jangan' di depan kalimat, perkembangan interogatif yang terdiri dari pertanyaan, perkembangan penggabungan kalimat, dan perkembangan sistem bunyi.

c. Perkembangan Masa Sekolah

Pada masa perkembangan ini meliputi perkembangan struktur bahasa, pemakaian bahasa, dan kesadaran metalinguistik (pertumbuhan kemampuan untuk memikirkan, mempertimbangkan, dan berbicara mengenai bahasa sebagai sandi atau kode formal).

Tarigan (1988) menjelaskan beberapa tahapan perkembangan bahasa anak menurut Jean Piaget, antara lain:

Tabel 1

Tahapan Perkembangan Bahasa Anak

\begin{tabular}{|l|l|}
\hline \multicolumn{1}{|c|}{ Usia } & \multicolumn{1}{c|}{ Tahap Perkembangan Bahasa } \\
\hline $0.0-0.5$ & Tahap meraban (pralinguistik) pertama \\
\hline $0.5-1.0$ & Tahap meraban (pralinguistik) kedua : kata nonsense \\
\hline $1.0-2.0$ & Tahap linguistik I : holofraksis; kalimat satu kata \\
\hline $2.0-3.0$ & Tahap linguistik II : kalimat dua kata \\
\hline $3.0-4.0$ & Tahap linguistik III: pengembangan tata bahasa \\
\hline $4.0-5.0$ & Tahap linguistik IV : tata bahasa pradewasa \\
\hline $5.0-$ & Tahap V : kompetensi penuh \\
\hline
\end{tabular}

2. Pemerolehan Bahasa

Pada saat anak-anak sedang memperoleh bahasa pertamanya terdapat dua proses, yaitu proses kompetensi dan proses performansi. Kedua proses ini berbeda satu sama lainnya. Kompetensi merupakan sebuah proses penguasaan tata bahasa yang berlangsung tanpa disadari. Proses kompetensi ini merupakan syarat untuk terjadinya proses performansi yang terdiri dari dua proses, seperti proses pemahaman dan proses penerbitan atau proses menghasilkan kalimatkalimat. Proses pemahaman biasanya melibatkan kemampuan atau kepandaian mengamati atau memampuan mempersepsi kalimat-kalimat yang didengar. Penerbitan juga melibatkan kemampuan mengeluarkan atau menerbitkan 


\section{Halim Purnomo}

kalimat-kalimat sendiri. Kedua jenis proses kompetensi ini apabila telah dikuasai anak-anak akan menjadi kemampuan linguistik mereka. Jadi, kemampuan linguistik ini terdiri dari kemampuan memahami dan kemampuan menerbitkan kalimat-kalimat baru yang dalam linguistic generatif disebut perlakuan atau pelaksanaan bahasa, atau performansi.

Secara umum perkembangan anak menurut Yuliani (2010) dalam Saripudin (2019) terdapat beberapa prinsip yang perlu diperhatikan dalam pelaksanaan pembelajaran pada pendidikan anak usia dini meliputi orientasi pada perkembangan anak, orientasi pada kebutuhan anak, bermain sambil belajar atau belajar sambil bermain, stimulasi terpadu, lingkungan kondusif, menggunakan pendekatan tematik, aktif, kreatif, inovatif, dan menyenangkan, menggunakan berbagai media dan sumber belajar, mengembangkan kecakapan hidup serta pemanfaatan teknologi informasi.

a. Berorientasi pada perkembangan anak

Dalam melakukan kegiatan, pendidik perlu memberikan kegiatan yang sesuai dengan perkembangan tahapan anak. Karena anak-anak memiliki ciri khas perbedaan masing-masing individu, sehingga sangat perlu diperhatikan. Oleh karena itu sangat diperlukan dan diperhatikan penyesuaian belajar dari mulai yang paling sederhana hingga pada yang paling sulit, dari mulai konkret ke abstrak, gerakan ke verbal, dan ke aku-an ke rasa social.

b. Berorientasi pada kebutuhan anak

Anak pada usia dini sedang membutuhkan proses belajar untuk mengoptimalkan semua aspek perkembangannya. Berbagai jenis kegiatan pembelajaran hendaknya dilakukan berdasarkan pada perkembangan dan kebutuhan masing-masing anak karena memiliki kapasitas berbeda-beda.

c. Bermain sambil belajar atau belajar sambil bermain.

Bermain merupakan salah satu pendekatan pembelajaran pada anak selama proses pembelajaran berlangsung. Situasi yang menyenangkan merupakan hal yang tidak bisa ditinggalkan selama proses pembelajaran. Berbagai strategi, metode, materi, bahan dan media harus dikembangkan agar anak dapat terarah pada focus pembelajaran. Melalui kegiatan bermain anak diajak untuk berekplorasi, menemukan dan memanfaatkan objek-objek yang dekat dengan anak. 
Para ahli bahasa seperti Aitchison dalam Tussholehah (2015) mengemukakan beberapa tahap pemerolehan bahasa anak, yaitu tahap mendengkur, tahap meraban, tahap pola intonasi, tahap tuturan satu kata, tahap tuturan dua kata, tahap infleksi kata, tahap bentuk tanya dan bentuk ingkar, tahap konstruksi yang jarang atau kompleks, dan tahap tuturan yang matang. Selanjutnya Arisanti (2014) menjelaskan bahwa terdapat dua aliran teori pemerolehan bahasa yang saling bertolak belakang, yaitu aliran behaviorisme dan aliran mentalisme. Aliran behavioristik lebih mendasari teori belajar dalam proses pemerolehan bahasa yang mementingkan lingkungan verbal dan non verbal.

Teori mentalistic lebih focus hanya mengambil struktur dan cara kesadaran sebagai dasarnya. Aliran behavioristik ini dalam proses pemerolehan bahasa mendasari teori belajar yang mementingkan lingkungan verbal dan nonverbal. Teori belajar yang menekankan adanya kemampuan lahiriah pada seorang anak untuk belajar suatu bahasa merupakan focus dari aliran teori mentalistik. Oleh karena itu, para behavioris lebih menyukai istilah belajar bahasa (language learning) dan para mentalis lebih menyukai istilah pemerolehan bahasa (language acquisition).

\section{Bahasa Daerah Sebagai Bahasa Ibu Anak}

Kemajuan masa depan bangsa akan diisi oleh anak-anak yang sekarang masih menjadi bagian dari masyarakat sebagai generasi penerus kemajuannya. Kertas kosong merupakan sebuah ibarat yang sering dikaitkan dengan keberadaan psikologis anak yang tumbuh kembangnya sangat dipengaruhi oleh komunitas lingkungan di mana mereka lebih banyak berinteraksi. Budaya bahasa jawa sebagai warisan luluhur bangsa perlu dijaga dan dikembangkan sekaligus sebagai kekayaan bangsa yang harus tetap dilestarikan seperti bahasa budaya dan daerah yang ada di Indonesia.

Oleh sebab itu sebagai bentuk penanaman rasa cinta terhadap tanah air, sangat diperlukan karakter cinta tanah air yang harus diestafetkan dari generasi ke generasi selanjutnya. Pesatnya kemajuan jaman dan semakin terbukanya jalur-jalur komunikasi dapat memungkinkan kebudayaan nasional dengan mudahnya memudar. Oleh karena itu warisan nenek moyang bangsa harus ditanamkan kepada anak-anak sebagai leluhur dan bahasa ibu telah digunakan sejak lama.

Bahasa ibu sebagai bahasa pertama anak secara harfiah disebut dengan mother language merupakan bahasa pertama yang dipelajari oleh semua orang sejak menjadi 


\section{Halim Purnomo}

bagian dari keluarga. Biasanya bahasa dasar pertama yang dipelajari anak merupakan bahasa yang seringkali digunakan oleh keluarganya. Dasar cara berpikir hanya bisa dengan penguasaan bahasa. Karena kepandaian memahami bahasa asli memiliki peran yang sangat penting untuk proses belajar berikutnya.

Kesulitan dalam memahami budaya dan kesulitan belajar seringkali disebabkan karena kesulitan memahami bahasa pertama. Bahasa asli memiliki peran yang sangat penting dalam proses Pendidikan. Misalnya saja di berbagai daerah atau sebut saja Pasundan bahasa daerahnya bahasa Sunda, bahasa daerah yang ada di Indonesia seperti bahasa Jawa, bahasa Batak, bahasa Ambon, bahasa Sunda dan bahasa-bahasa daerah lainnya. Berikut ini merupakan upaya-upaya pengembangan bahasa daerah tetap dari ancaman kepunahan adalah sebagai berikut :

a. Mempopulerkan kembali cerita rakyat dalam tradisi lisan dalam bahasa daerah setempat.

b. Peran orangtua harus tetap menjadi guru utama dan tetap memelihara bahasa daerah di rumah dalam membangun komunikasi dengan anak-anak. Harus diberi pemahaman yang holistic bahwa bahasa daerah sangat penting dalam melestarikan budaya dan membangun jati diri.

c. Program pembelajaran bermuatan local harus disertai dengan buku yang ditulis dalam bahasa daerah yang ditetapkan sebagai bahasa lokal setempat.

d. Dalam hubungan dengan pengaruh teknologi televisi dan radio, maka Pemerintah Daerah harus menetapkan penyiaran mata acara tertentu harus menggunakan bahasa daerah.

Bahasa daerah yang terdapat di tiap-tiap daerah digunakan sebagai alat komunikasi dan interaksi antara orang yang satu dengan yang lain. Bahasa daerah umumnya merupakan bahasa pertama bagi anggota masyarakat di daerah yang bersangkutan. Oleh karena itu dapat dipastikan bahwa setiap anggota masyarakat yang hidup di suatu daerah mengerti dan mampu menggunakan bahasa daerahnya. Karena Hilangnya bahasa ibu juga berarti hilangnya masa depan kebudayaan dan rasa menjadi bagian dari suatu masyarakat.

Selanjutnya untuk lebih memperjelas tahap-tahap pemerolehan bahasa pertama, maka di bawah ini diuraikan tahap-tahap pemerolehan bahasa seorang anak. Menurut Fatmawati (2015) tahap pemerolehan bahasa dibagi menjadi empat tahap, yaitu praujaran, meraban, tahap satu kata, dan tahap penggabungan kata sebagai berikut:

1. Tahap Pralinguistik (Masa Meraba) 
Pada masa ini apapun bunyi yang keluar belum memiliki makna. Bunyi yang keluar tanpa tatanan bahasa dan hanya berupa vokla dan konsonan tertentu. Tetapi, secara keseluruhan bunyi tersebut tidak mengacu pada kata dan makna tertentu. Fase ini berlangsung sejak anak lahir sampai berumur 12 bulan.

2. Pada umur 0-2 bulan, anak hanya mengeluarkan bunyi-bunyi refleksif untuk menyatakan rasa lapar, sakit, atau ketidaknyamanan. Sekalipun bunyi-bunyi itu tidak bermakna secara bahasa, tetapi bunyi-bunyi itu merupakan bahan untuk tuturan selanjutnya.

3. Pada umur 2-5 bulan, anak mulai mengeluarkan bunyi-bunyi vocal yang bercampur dengan bunyi-bunyi mirip konsonan. Bunyi ini biasanya muncul sebagai respon terhadap senyum atau ucapan ibunya atau orang lain.

4. Pada umur 4-7 bulan, anak mulai mengeluarkan bunyi agak utuh dengan durasi yang lebih lama. Bunyi mirip konsonan atau mirip vokalnya lebih bervariasi.

5. Pada umur 6-12 bulan, anak mulai berceloteh. Celotehannya merupakan pengulangan konsonan dan vokal yang sama seperti/ba ba ba/, ma ma ma/, da da da/.

a. Tahap satu - kata

Fase ini biasanya terjadi pada anak berusia 12-18 bulan. Pada masa ini, anak menggunakan satu kata yang memiliki arti yang mewakili keseluruhan idenya. Tegasnya, satu kata mewakili satu atau bahkan lebih frase atau kalimat. Oleh karena itu, frase ini disebut juga tahap holofrasis.

b. Tahap dua - kata

Fase ini berlangsung sewaktu anak berusia sekitar 18-24 bulan. Pada masa ini, kosakata dan gramatika anak berkembang dengan cepat. Anak-anak mulai menggunakan dua kata dalam berbicara. Tuturannya mulai bersifat telegrafik. Artinya, apa yang dituturkan anak hanyalah kata-kata yang penting saja, seperti kata benda, kata sifat, dan kata kerja. Kata-kata yang tidak penting, seperti halnya kalau kita menulis telegram, dihilangkan.

c. Tahap banyak - kata

d. Fase ini berlangsung ketika anak berusia 3-5 tahun atau bahkan sampai mulai bersekolah. Pada usia 3-4 tahun, tuturan anak mulai lebih panjang dan tata bahasanya lebih teratur. Dia tidak lagi menggunakan hanya dua kata, tetapi tiga kata atau lebih. Pada umur 5-6 tahun, bahasa anak telah menyerupai bahasa orang dewasa. 


\section{Bahasa Indonesia Sebagai Bahasa Kedua Anak}

Bahasa Indonesia merupakan bahasa persatuan, bahasa ini diciptakan untuk mempersatukan bangsa Indonesia yang terdiri dari bermacam-macam suku, budaya, dan bahasa. Dengan menggunakan bahasa Indonesia, setiap orang yang berasal dari daerah yang berbeda dapat saling memahami satu sama lain, karena mereka berkomunikasi menggunakan satu bahasa, yaitu bahasa Indonesia. Bahasa Indonesia selain sebagai pemersatu, juga sebagai salah satu budaya Indonesia, karena bahasa Indonesia merupakan identitas bangsa di kancah Internasional.

Ketika negara Republik Indonesia baru didirikan, yaitu pada awal 1950-an, banyak bangsa lain yang menyatakan kekagumannya terhadap bangsa Indonesia karena dua hal. Pertama, karena berbeda dengan negara lainnya, Indonesia merebut kemerdekaan dengan cara perjuangan fisik serta diplomasi yang cukup seru, sehingga melibatkan PBB dan negara-nagara maju lainnya. Kedua, karena bangsa Indonesia sejak awal sudah memiliki bahasa nasional sendiri, yaitu bahasa Indonesia (Rosidi, 2010: 51). Pengajaran bahasa Indonesia secara formal dimulai ketika anak memasuki pendidikan dasar (kirakira berusia 6 tahun) untuk bahasa nasional. Ini perlu, karena upaya dalam mempertahankan dan melestarikan bahasa Indonesia sebagai bahasa kedua perlu diajarkan sedini mungkin.

Chaer (2009) menyatakan bahwa pemerolehan bahasa atau akuisisi bahasa adalah proses yang berlangsung di dalam otak seorang anak ketika dia memperoleh bahasa pertamanya atau bahasa ibunya. Pemerolehan bahasa biasanya dibedakan dari pembelajaran bahasa (language learning). Pembelajaran bahasa berkaitan dengan proses-proses yang terjadi pada waktu seorang kanakkanak mempelajari bahasa kedua, setelah ia memperoleh bahasa pertamanya. Jadi, pemerolehan bahasa berkenaan dengan bahasa yang pertama, sedangkan pembelajaran bahasa berkenaan dengan bahasa kedua. Selanjutnya Chaer juga menjelaskan anak-anak pada usia 5 tahun telah dapat menguasai pola bahasa pertamanya, betapa pun pola bahasa itu sangat ruwet bagi orang asing. Dengan demikian, ketika anak Indonesia (yang bahasa pertamanya adalah bahasa daerah) mulai mempelajari bahasa Indonesia mereka sudah terbiasa dengan pola-pola bahasa pertamanya.

Menurut Chaer dan Agustina mengatakan bahwa dalam mempelajari bahasa kedua (baca: bahasa Indonesia) perlu diperhatikan perbedaan-perbedaan pola yang terdapat 


\section{Halim Purnomo}

antara bahasa pertama yang telah dikuasai dengan pola-pola bahasa Indonesia. Begitu juga dengan latar belakang budaya yang perlu dipertimbangkan. Di Indonesia pada umumnya bahasa Indonesia adalah bahasa kedua (yang secara politis juga berstatus sebagai bahasa nasional dan bahasa resmi kenegaraan). Faktor-faktor penentu dalam pembelajaran bahasa kedua dari berbagai hipotesis yang berkembang, dapat ditentukan beberapa faktor yang dapat menentukan keberhasilan bahasa kedua, yaitu faktor motivasi, usia, penyajian formal, bahasa pertama, serta lingkungan.

a. Faktor Motivasi

Terdapat asumsi bahwa jika kita mau belajar suatu bahasa kedua, maka yang diperlukan adalah adanya dorongan, keinginan, atau tujuan yang hendak dicapai. Ini akan berbeda jika dibandingkan dengan orang yang tanpa lindasi dorongan, keinginan, serta tujuan atau motivasi. Menurut KBBI (2008), motivasi adalah dorongan yang timbul pada diri seseorang secara sadar atau tidak untuk melakukan suatu tindakan dengan tujuan tertentu. Jadi, pada dasarnya motivasi dalam pembelajaran bahasa berupa dorongan yang datang dari dalam diri pembelajar yang menyebabkan ia memilki keinginan yang kuat untuk mempelajari bahasa kedua.

Menurut Gardner dan Lambert (dalam Chaer: 2009: 251), motivasi memiliki dua fungsi yaitu, fungsi integratif dan instrumental. Fungsi integratif yaitu jika motivasi tersebut mendorong seseorang untuk mempelajari suatu bahasa karena adanya keinginan untuk berkomunikasi dengan masyarakat penutur bahasa itu atau menjadi anggota masyarakat bahasa tersebut. Sedangkan, motivasi berfungsi instrumental adalah jika motivasi tersebut mendorong sesorang memilki kemauan untuk mempelajari bahasa kedua itu karena tujuan yang bermanfaat atau karena dorongan ingin memperoleh suatu pekerjaan atau mobilitas sosial pada masyarakat bahasa tersebut.

b. Faktor Usia

Terdapat anggapan bahwa dalam mempelajari bahasa kedua, anak-anak lebih baik dan berhasil dari pada orang dewasa (jika dimulai dari sama-sama nol). Ini membuktikan bahwa ternyata selain faktor motivasi, ternyata faktor usia juga ikut andil dalam keberhasilan mempelajari bahasa kedua. Anak-anak sepertinya lebih mudah untuk cepat memahami, sedangkan orang dewasa tampaknya lebih kesulitan dalam memperoleh tingkat kemahiran bahasa kedua. Hasil penelitian yang dilakukan oleh beberapa ahli (Chaer, 2009) memperoleh kesimpulan bahwa faktor umur (usia) yang tidak dipisahkan dengan faktor lain, adalah faktor yang 


\section{Halim Purnomo}

berpengaruh dalam pembelajaran bahasa kedua. Perbedaan umur memengaruhi kecepatan dan keberhasilan belajar bahasa kedua pada aspek fonologi, morfologi, dan sintaksis, tetapi tidak berpengaruh dalam pemerolehan urutannya.

c. Faktor Penyajian Formal

Pada pembahasan sebelumnya, tipe pembelajaran bahasa terdiri dari dua jenis, yaitu secara naturalistik dan formal di dalam kelas. Faktor formal dalam pendidikan di sekolah akan sangat berpengaruh dalam hal pembelajaran bahasa kedua. Bahasa kedua bisa diorientasikan ke dalam bahasa Indonesia, bisa juga bahasa asing (jika bahasa Indonesia merupakan bahasa pertama). Tipe ini berlangsung secara formal, artinya segala sesuatunya sudah dipersiapkan secara lebih baik. Dengan adanya guru, materi yang terorganisir, kurikulum, metode, media belajar, dsb.

Faktor ini memiliki pengaruh terhadap kecepatan dan keberhasilan dalam memperoleh bahasa kedua karena berbagai faktor dan variabel telah dipersiapkan dan diadakan secara sengaja sehingga tujuan akan cepat terpenuhi. Rofi'udin (dalam Chaer: 2009) berpendapat bahawa interaksi kelas merupakan bagian dari pembelajaran bahasa kedua secara formal dapat memberikan pengaruh terhadap kecepatan pemerolehan bahasa kedua. Interaksi kelas, selain itu juga dapat mendukung proses penyerapan input menjadi intake.

d. Faktor Bahasa Pertama

Para pakar pembelajaran bahasa kedua menurut Ellis (dalam Chaer, 2009) pada umumnya percaya bahwa bahasa pertama seperti bahasa ibu, bahasa daerah, atau bahasa yang sebelumnya diperoleh mempunyai pengaruh terhadap proses penguasaan bahasa kedua pembelajar. Hal ini karena didasarkan oleh sikap pembelajar yang secara sadar maupun tidak, telah melakukan transfer unsur-unsur bahasa pertamanya ketika menggunakan bahasa kedua. Akibatnya, sering terjadi interferensi, alih kode, atau campur kode.

Pada pengajaran bahasa kedua tentu akan menimbulkan masalah-masalah sosiolinguistik. Menurut Chaer (2010) masalah ini mungkin tidak terlalu berat, kalau kebetulan bahasa kedua yang dipelajari itu masih tergolong bahasa serumpun (secara genetis) tetapi akan merupakan masalah besar kalau bahasa kedua itu tidak serumpun dengan bahasa pertama. Lebih lagi jika bahasa kedua itu memilki struktur fonetis, morfologis, dan sintaksis yang sangat berbeda dengan bahasa pertama. 
Kaum Behaviorisme dalam teori stimulus-respon yang dikemukakan bahasa merupakan hasil dari perilaku stimulus-respon. Jadi, bahasa pertama dalam bentuk transfer ketika berbahasa kedua akan besar sekali apabila si pembelajar tidak terusmenerus diberikan stimulus bahasa kedua. Secara teoritis pengaruh ini memang tidak bisa dihilangkan karena bahasa pertama sudah merupakan merupakan intake atau sudah "dinuranikan" dalam diri si pembelajar. Namun, dengan pembiasaanpembiasaan dan pemberi stimulus terus-menerus dalam bahasa kedua, maka pengaruh itu bisa dikurangi (Chaer, 2010).

Selanjutnya adalah teori kontrastif menurut Klein dalam Chaer (2009), teori ini dikatakan bahwa keberhasilan sebuah pembelajaran bahasa kedua ditentukan oleh keadaan linguistik bahasa yang telah dikuasai sebelumnya oleh si pembelajar. Teori kontrastif ini mengisyaratkan bahwa semakin besar perbedaan antara linguistik bahasa pertama dengan linguistik bahasa kedua, maka semakin besar kesulitan yang dihadapi si pembelajar dalam usaha menguasai bahasa kedua. Melalui teori ini, maka dapat diketahui tingkat kesamaan dan perbedaan antara bahasa pertama dengan bahasa kedua. Setelah mengetahui tingkat kesamaan dan perbedaan tersebut, maka dapat ditentukan strategi apa yang dapat digunakan untuk mengajarkan bahasa kedua.

e. Faktor Lingkungan

Faktor lingkungan ini juga sangat penting dalam menentukan keberhasilan pembelajaran bahasa kedua. Faktor ini terbagi menjadi dua wilayah, yaitu pengaruh lingkungan formal di sekolah dan lingkungan informal atau alamiah.

f. Pengaruh Lingkungan Formal

Lingkungan formal merupakan lingkungan dalam belajar bahasa yang memfokuskan pada penguasaan kaidah-kaidah bahasa seperti aspek-aspek linguistik yang sedang dipelajari secara sadar dan disengaja. Sebenarnya, lingkungan formal bahasa bukanlah terbatas pada kelas, karena yang penting dalam pembelajaran bahasa tersebut dilakukan secara sadar dan mengetahui kaidahkaidah bahasa kedua yang dipelajarinya, baik dari guru saat di dalam kelas, dari buku-buku, maupun orang lain di luar kelas. Yang terpenting, lingkungan tersebut menekankan pada penguasaan kaidah bahasa pada pembelajaran secara sadar.

g. Pengaruh Lingkungan Informal

Lingkungan ini bersifat alami atau natural, tidak direkayasa yang menurut Chaer (2009) termasuk dalam lingkungan informal ini merupakan bahasa yang 
digunakan kawan-kawan sebaya, bahasa pengasuh atau bahasa orangtua, bahasa yang digunakan anggota kelompok etnis pembelajar, yang digunakan media massa, bahasa para guru, baik di kelas maupun di luar kelas.

\section{Bahasa Inggris Bukan Bahasa Asing Bagi Anak}

Bahasa asing di era globalisasi ini bukan lagi menjadi bahasa asing, melainkan menjadi tuntutan untuk dikuasai baik secara writing maupun oral. Tuntutan tersebut terbukti dengan orangtua berlomba-lomba memasukkan anak mereka ke sekolah yang bertaraf internasional ataupun nasional plus dimana media bahasa yang digunakan adalah bahasa Inggris. Bahasa Inggris telah menjadi bahasa Internasional yang digunakan hampir disegala bidang kehidupan global. Bahasa Inggris juga telah menjadi bahasa dunia yang mendominasi era komunikasi untuk menghubungkan dan mentransfer ilmu ke seluruh dunia. Hal ini memberikan asumsi bahwa penguasaan bahasa Inggris merupakan kebutuhan yang sangat penting bagi masyarakat modern sekarang ini karena penguasaan terhadap bahasa Inggris memudahkan seseorang untuk memperluas pergaulannya di dunia internasional.

Penelitian Rahayu (2012) pada aspek percakapan anak berpendapat bahwa, pertama jenis konjungsi yang dikuasai anak usia 7-9 tahun yaitu konjungsi koordinatif, konjungsi subordinatif, dan konjungsi subordinatif-koordinatif. Berdasarkan bentuk pemakaiannya, konjungsi koordinatif tersusun menjadi tunggal dan ganda. Konjungsi koordinatif tunggal merupakan konjungsi yang terdiri atas satu kata dalam satu kalimat yang biasanya terdiri dari konjungsi dan, sedangkan, tapi, atau, terus, habis itu, jadi, serta lagipula. Konjungsi koordinatif ganda merupakan konjungsi yang terdiri atas dua kata dalam satu kalimat di antaranya adalah konjungsi tapi-dan, dan-tapi, terus-jadinya, serta terus-tapi. Konjungsi subordinatif yang digunakan dalam bahasa percakapan anak usia 7-9 tahun antara lain konjungsi ketika, setelah, waktu, sambil, kalau, asal, sebab, karena, supaya, sampai, seandainya, dan misalnya.

Konjungsi subordinatif-koordinatif untuk percakapan dikalangan anak-anak usia 7-9 tahun biasanya terdiri dari konjungsi kalau-terus, serta supaya-dan. Konjungsi yang paling banyak digunakan biasanya konjungsi subordinatif persyaratan. Kedua realisasi pemakaian konjungsi yang ditemukan berdasarkan analisis tuturan percakapan anak usia 7-9 tahun antara lain pemakaian konjungsi yang tepat dan tidak tepat dalam menggabungkan konstituen kalimat. Pemakaian konjungsi yang tepat yaitu ketepatan konjungsi dalam menggabungkan konstituen kalimat sehingga membentuk hubungan yang logis. 


\section{Halim Purnomo}

Fromkin (1990) mengatakan bahwa: "English has been called 'the lingua franca of the world". Kedudukan Bahasa Inggris bagi masyarakat Indonesia masih merupakan bahasa asing pertama (the first foreign language). Kedudukan tersebut berbeda dengan bahasa kedua. Mustafa (2007) dalam hal ini menyatakan bahwa bahasa kedua merupakan bahasa yang dipelajari anak setelah bahasa ibunya dengan ciri bahasa tersebut digunakan dalam lingkungan masyarakat sekitar. Sedangkan bahasa asing merupakan bahasa negara lain yang tidak digunakan secara umum dalam interaksi sosial.

Bahasa Inggris di Indonesia bagi beberapa kalangan telah mejadi bahasa harian, akan tetapi belum berlaku bagi mayoritas lainnya, selain karena sebagian mereka belum semuanya menguasai secara penuh. Kedudukan bahasa Inggris di Indonesia masih jarang digunakan, hanya sebagian kecil masyarakat yang menggunakan dalam interaksi sosialnya kecuali di wilayah-wilayah yang sering dikunjungi wisatawan-wisatawan asing bahasa inggris menjadi bahasa yang sangat familier.

Bagi masyarakat yang tinggal di daerah-daerah yang sering dikunjungi wisatawanwisatawan asing mau tidak mau harus mmeiliki kemampuan bahasa asing. karena penguasaan bahasa Inggris merupakan keterampilan yang sangat penting dalam era informasi dan komunikasi saat ini. Hal ini sangat menentukan bagaimana kita dapat berinteraksi secara global. Isu globalisasi saat ini menuntut sumberdaya manusia yang berkualitas dan mampu berkomunikasi dalam berbagai bahasa asing terutama bahasa Inggris sebagai bahasa internasional. Keahlian berbahasa asing ini diperlukan untuk menguasai ilmu pengetahuan, memiliki pergaulan luas dan karir yang baik. Hal ini membuat semua orang dari berbagai kalangan termotivasi untuk mengusai bahasa Inggris. Istilah pemerolehan (acquisition) bahasa menurut Dardjowidjojo (2010) dalam Arsanti (2014) berarti proses penguasaan bahasa yang dilakukan oleh anak secara natural pada waktu ia belajar bahasa ibunya (native language). Istilah ini berbeda dengan pembelajaran (learning), yakni proses yang dilakukan dalam tataran yang formal (belajar di kelas dan diajar oleh seorang guru). Dengan demikian, proses dari anak yang belajar menguasai bahasa ibunya adalah pemerolehan, sedangkan proses dari orang (umumnya dewasa) yang belajar di kelas adalah pembelajaran.

Dorongan orang tua memasukkan anak-anaknya untuk mempelajari khsuus bahasa asing sebagia bentuk support mereka agar memiliki kemampuan penguasaan bahasa asing seklaigus agar kelak mampu beradaptasi dengan perubahan dan tuntutan berkomunikasi dengan orang asing. Hal ini sebagaimana diasumsikan oleh Santrock 
(2007) bahwa masa usia anak-anak akan lebih cepat menguasai bahasa asing dibandingkan dengan orang dewasa. Hal ini disepakati juga oleh Johnson dan Newport (1991 dalam Santrock, 2007) dari hasil penelitiannya yang menjelaskan bahwa imigran asal China dan Korea usia 3-7 tahun yang tinggal di Amerika kemampuan bahasa Inggrisnya lebih baik dari pada orang tua atau orang dewasa. Hal serupa sesuai dengan penelitian Musthaafa (2007), bahwa anak yang menguasai bahasa asing memiliki kelebihan dalam hal intelektual yang fleksibel, keterampilan akademik, berbahasa dan sosial. Selain itu, anak akan memiliki kesiapan memasuki suatu konteks pergaulan dengan berbagai bahasa dan budaya. Sehingga ketika dewasa anak akan menjadi sumber daya manusia yang berkualitas dan bisa berprestasi.

Mustafa (2007) menambahkan bahwa pemahaman dan apresiasi anak terhadap bahasa dan budayanya sendiri juga sangat dimungkinkan akan mengalami perkembangan jika mulai mempelajari bahasaasing sejak dini. Alasan mendasarnya karena mereka akan memiliki akses yang lebih besar terhadap bahasa dan budaya asing. Akan tetapi, pengajaran bahasa Inggris di Indonesia berbeda dengan pengajaran bahasa Inggris sebagai bahasa kedua di negara di mana bahasa Inggris sebagai media komunikasi.

Bahasa Inggris bagi sebagian besar kalangan anak-anak bukan menjadi alat komunikasi harian sehingga berbeda dengan bahasa pertama anak-anak seperti bahasa Indonesia, Jawa, Sunda, dan bahasa daerah yang lain di Indonesia. Perbedaan kebahasaan ini penting untuk dipahami agar pembelajaran dapat dipertanggungjawabkan kebenarannya. Perbedaan-perbedaan tersebut antara lain: ucapan, ejaan, struktur bahasa, tekanan dan intonasi, kosakata, dan nilai kultur bahasa asing. Bahasa Inggris juga diketahui sebagai bahasa yang cermat waktu (tenses), cermat angka (singular-plural), dan cermat orang (feminine dan maskulin).

Perhatian utama sebelum pembelajaran adalah menentukan piilihan materi yang sesuai dengan usia anak dan juga efektif untuk perkembangan kognitif bahasa anak serta situasi belajar yang menyenangkan haruslah menjadi perhatian utama dalam berhasilnya suatu proses pembelajaran. Keberhasilan proses pembelajaran bahasa Inggris pada anak usia dini tentunya dipengaruhi oleh banyak faktor, antara lain:

1. Guru yang dapat menghidupkan proses kegiatan belajar mengajar termasuk kategori guru kompeten.

2. Fasilitas dan bumber pembelajaran yang memadai dan memenuhi syarat

3. Kurikulum yang baik, sederhana, dan menari. 


\section{Halim Purnomo}

Di sisi lain perlu dipahami bahwa usia dini merupakan masa usia bermain. Setiap anak merupakan pribadi yang memiliki karakter unik dan dunia bermain merupakan kegiatan yang serius namun mengasyikan bagi mereka. Maka pendekatan dan model yang tepat perlu diciptakan dan dihadirkan oleh seorang pendidik agar proses pembelajaran bahasa Inggris lebih menarik dan menyenangkan serta menghadirkan rasa penasaran tinggi tanpa meninggalkan kaidah-kaidah bahasa yang benar. Pendekatan serta model yang sebaiknya digunakan hendaknya sejalan dengan tujuan pengenalan bahasa pada umumnya. Tujuan tersebut agar anak dapat memahami cara berbahasa yang baik dan benar, berani mengungkapkan ide atau pendapatnya dan dapat berkomunikasi dengan lingkungannya. Berikut ini metode-metode atau Teknik-teknik dalam pembelajaran bahasa Inggris, antara lain:

a. Kemampuan berccerita, atau istilah ini disebut denga Story Telling.

b. Bermain peran, atau istilah ini dikenal dengan Role Play.

c. Karya seni dan kerajinan tangan, atau istilah ini dikenal dengan Art and Crafts.

d. Permainan, atau isti;lah ini disebut dengan Games.

e. Menunjukkan dan mejelaskan, atau istilah ini disebut denga Show and Tell.

f. Gerak dan lagu, atau dalam ilmu music dikenal dengan music and movement yang di dalamnya termasuk Singing (Nyanyian), Chants and Rhymes (Nyanyian Pendek maupun Sajak), dan sebagainya.

Kemampuan guru dalam memilih, menggunakan dan mengembangkan nyanyian yang ada agar nyanyian tersebut dapat disajikan dan dipahami oleh anak secara baik tanpa melupakan kaidah berbahasa Inggris yang baik dan benar merupakan sumber utama yang bisa digunakan. Pemerolehan bahasa anak usia 3 tahun sebagaimana dijelaskan dari hasil penelitian Saputri (2018) bahwa pemerolehan bahasa pada anak suai 3 tahun masih pada tataran morfologi yang berupa prefik, sufiks dan pemerolehan sintaksis yang meliputi kalimat deklaratif dan imperatif. Lingkungan anak merupakan satu-satunya yang harus didukung agar menjadi sumber utama pemerolehan bahasa yang baik.

\section{Mekanisme perolehan bahasa}

a. Imitasi, terjadi biasanya pada anak berlatih menirukan pola bahasa maupun apa saja yang didengar oleh anak dari orang tuanya.

b. Pengkondisian sebagaimana yang dikembangkan oleh B. F. Skinner. Kata benda biasanya menjadi kosakata awal bagi anak. Mekanisme pembiasaan maupun pengkondisian pada ucapan yang seringkali terjadi pada anak. 
c. Kognisi sosial, kata atau semantic dipahami oleh anak karena secara kognisi ia memahami tujuan seseorang menghasilkan suatu fonem melalui mekanisme atensi secara bersama. Biasanya bahasa terproduksi melalui mekanisme imitasi.

\section{SIMPULAN}

Secara psikologis bahasa anak dipengaruhi oleh apa-apa yang sering didengar dari media langsung maupun tidak langsung. Media langsung yang maksud merupakan media yang diberikan baik oleh orangtua, guru maupun tutor. Sedangkan media tidak langsung merupakan media yang diperoleh anak biasanya pada saat berinteraksi dengan teman sebaya, mendengar dan menyaksikan dari media televisi maupun media lainnya serta pemerolehan bahasa dari aspek pendengaran yang diterima

\section{DAFTAR PUSTAKA}

Budiyono, Herman (2012). Pemeblajaran Keterampilan Menulis Berbasis Prose Menulis Pada Teori Pemerolehan Bahasa, Pena, Vol. 2, No. 3, Desember.

Chaer, Abdul (2009). Psikolinguistik Kajian Teoritik. Jakarta : Rineka Cipta.

Dardjowidjojo, Soenjono (2010). Psikolinguistik Pengantar Pemahaman Bahasa Manusia. Jakarta: Yayasan Obor Indonesia.

Djuwwarijah, Siti (2017). Pemerolehan Bahasa Telegram Dan Kalimat Anak Sekolah Dasar dan Prasekolah, KONSTRUKTIVISME, No. 9, Vol. 1, Januari.

Fatmawati, Suci Rani (2015). Pemerolehan Bahasa Pertama Anak Menurut Psikolinguistik, Lentera, Vol. XVIII, No. 1 Juni.

Iskandarwassid dan Dadang Sunendar (2009). Strategi Pembelajaran Bahasa. Bandung: Remaja Rosda Karya.

Meilan, Arsanti (2014). Pemerolehan Bahasa Pada Anak (Kajian Psikolinguistik), Jurnal PBSI, Vol. 3, No. 2,

Mulyaningsih, Indrya (tt). Pemerolehan Bahasa Anak Pada Usia Empat Tahun Dengan Whole Language, AWLADY: Jurnal Pendidikan Anak, syekhnurjati.ac.id

Rahayu, Oktorika Kissanti (2012). Pemakaian Konjungsi Pada Bahaasa Percakapan Anak Usia 7-9 Tahun Di Desa Pabelan Kec. Kertasura Kab. Sukoharjo, Naskah Publikasi: Universitas Muhammadiyah Surakarta.

Saputri, Ria (2018). Pemerolehan Bahasa Pada Anak Usia 3 Tahun, Jurnal Linguistik, Sastra dan Pendidikan (Jurnal Istrundi), Vol. 2 No. 4. 


\section{Halim Purnomo}

Syahid, Ahmad Habibi (2015), Bahasa Arab Sebagai Bahasa Kedua (Kajian Teoritis Pemerolehan Bahasa Arab Pada Siswa Non-Native), Arabiyat: Jurnal Bahasara Arab dan Kebahasaan, Vol. 3, No. 1, halaman 86-97.

Saripudin, A. (2019). Analisis Tumbuh Kembang Anak Ditinjau Dari Aspek Perkembangan Motorik Kasar Anak Usia Dini, Equilita, Vol. 1 Issue 1, Agustus.

Tarigan, Henry Guntur (1988). Pengajaran Pemerolehan Bahasa. Bandung : Angkasa.

Tussolekha, Rohmah (2015). Pemerolehan Bahasa Anak Usia Satu dan Lima Tahun, Jurnal Pesona, Vol. 1, No. 7, Januari, hlmn. 59-70.

Wulandari, Desi Indah (2018). Pemerolehan Bahasa Indonesia Anak Usia 3-5 Tahun Di PAUD Lestari Desa Blimbing Kec. Paciran Kab. Lamongan, Lingua Franca: Jurnal Bahasa, Sastra dan Pengajarannya, Vol. 6, No. 1, Februari.

Yanris (2009). Kelahiran Bahasa dan Pemerolehan Bahasa pada Anak.

Yanti, Prima Gusti (2016). Pemerolehan Bahasa Abak Kajian Aspek Fonologi Pada Anak Usia 2-2,5 Tahun, Jurnal Ilmiah VISI PPTK PAUDNI, Vol. 11, No. 2, Desember. 